\title{
HISTORICAL LEGACIES IN A RAPIDLY CHANGING WORLD
}

\author{
If you're not at the table, you're on the menu. \\ - Slogan used by campaigners for an intergovernmental tax body \\ at the United Nations
}

The landscape of global economic governance is changing, moving away from that which characterized most of the negotiations discussed in this book. As power shifts away from the OECD countries, the institutions of the liberal economic order face an existential threat. ${ }^{1}$ As Richard Eccleston has argued, "The extent and nature of international cooperation [are] increasingly dependent on the foreign economic policy priorities of China and other emerging powers."2 Lowerincome countries are becoming more organized, but they are also more clearly divided, with the interests of large emerging markets and lower-income countries not always aligned. As we saw in chapters 6 and 7, low-income countries now face their toughest demands when negotiating tax treaties with China.

The multilateral institutions of global tax governance are not immune from this shifting terrain. The usual forum for debates about the organizational infrastructure of global tax governance is the United Nations' Financing for Development process. This is the highest political level at which the status of the UN Tax Committee-responsible among other things for drafting the UN model tax treaty-is discussed. Calls from the G77 group of lower-income countries to upgrade the committee to a full intergovernmental body have been a regular part of this process since 2002, but they reached a new peak in 2015 when a summit in Addis Ababa nearly fell apart. G77 members were adamant that the committee be upgraded, while OECD member states were implacably opposed. With development aid at risk if the conference collapsed, the lower-income countries eventually capitulated. ${ }^{3}$ 
The slogan quoted above has gone mainstream. In 2015, it featured on a banner unfurled by protesters at the United Nations, but by the time of a conference in the UN's New York headquarters in 2018 it had been appropriated by Pascal Saint-Amans, the director of the OECD's Centre for Tax Policy and Administration. In 2013, the OECD opened up its corporate tax franchise to the G20 members, inviting emerging markets to participate in all its tax work on an equal footing. The result is that a small but discernible Chinese imprint, for example, is visible on the latest drafts of the OECD's transfer pricing guidelines. ${ }^{4}$ Since 2016, all lower-income countries have since been invited to participate in an Inclusive Framework covering the implementation of the OECD's anti-tax-avoidance package (known as base erosion and profit shifting, or BEPS); more than one hundred countries, among them the UK, Vietnam, and Zambia, have joined. Others, such as Cambodia, remain skeptically on the outside. While campaigners initially criticized the Inclusive Framework because its mandate was limited to the implementation of standards developed by the OECD and G20, it has become the vehicle through which new policy challenges, notably the controversy about the application of international tax norms to the digital economy, are being addressed. That particular challenge appears to have irreconcilably broken the consensus among OECD members that has lasted for over a century, leaving them less united-and hence more vulnerable - than ever before. ${ }^{5}$

This book therefore comes at a time of great change, and of potential opportunities and risks for lower-income countries. They face a strategic dilemma. On the one hand, the opening at the OECD offers the possibility to shape the tools of international tax cooperation, especially the model treaties, in ways that allow lower-income countries to benefit from participation in the tax treaty regime without needing to give up so much tax revenue. Cancellations, renegotiations, and policy reviews across lower-income countries, together with the entry of new political actors into the politics of tax treaties, suggest the potential to stake out a new, more assertive position. On the other hand, as Tsilly Dagan has suggested, there is good reason to fear that lower-income countries will be the losers from apparently inclusive tax cooperation. ${ }^{6}$ In what follows, I reflect on the implications for this situation of historical North-South politics, and sound a note of caution.

\section{How We Got Here: A Brief Summary}

The term "double taxation agreement" conveys an idea that is powerful but misleading: that the purpose of the bilateral foundations of the international tax regime is to resolve a problem created by competing claims to tax inward cross-border 
investment, which will deter that investment. Tsilly Dagan argues that this logic is a myth, and as this book has shown, many actors in the process, including negotiators themselves, agree with her. Most notably, the United Kingdom's international tax officials in the 1970s, responsible for a huge program of negotiations, shared this view. Members of the international tax community abhor double taxation but recognize that even in the absence of a treaty it is unlikely to exist to a degree that will deter large amounts of investment in lower-income countries. Nonetheless, it is axiomatic that the conclusion of tax treaties is the appropriate way for a modern fiscal state to behave, because they embody a set of standards that have been elaborated by experts from the most advanced economies in a technocratic Parisian environment. Behind this apparently depoliticized front, however, we find a century of activity by officials from capital-exporting states to cement a bias in their favor into the international tax regime's multilateral core.

As actors in lower-income countries-fledgling fiscal states-have gained technical knowledge, they have been infused with this bias toward the OECDcentric approach. Vietnam, an unusually prolific negotiator, ensured that all its investors were covered by a tax treaty, even where there was little competitive pressure on it to do so. The way in which it applied those treaties, however, undermined any benefits that investors might have expected to gain from them. Zambia's international tax specialists negotiated and renegotiated agreements that they saw as a priority, but struggled until 2011 to persuade political veto players to sign and ratify them. As Cambodia succumbed to the inevitable logic of competition through tax treaties, its officials had to balance the need for support from external technical advisers with their advice that treaty provisions outside of the international models are not viable.

Meanwhile, the tax treaties myth prevails among actors who do not have this same technical knowledge. To them, signing tax treaties is one of the things that a country wishing to compete for investment does, even though there is not a solid evidence base to support this view. The choice of treaty partners illustrates this point: positive outliers such as Zambia and Vietnam, in negotiations during the 1970 s and 1990s, respectively, signed treaties with countries where there was little prospect that the treaty would lead to enhanced investment. These countries' high tax-to-GDP ratios insulated negotiators from more intense scrutiny of their choices, whereas in Cambodia and later in Zambia, the priority to raise more tax revenue from companies has contributed to more cautious approaches.

Negotiations by countries with limited technical expertise and a competitiondriven mentality also produced results in terms of the content of their agreements that illustrated the bounded rationality of their negotiating stance. When Zambia's and Vietnam's negotiations were motivated by competition, they also signed away taxing rights that their present negotiators regret. Had they fully appreciated the 
agreements they were signing, past negotiators might also have been more reluctant to give away so much.

Different ideas produced different priorities over what to negotiate with whom, and why. This is not to say, however, that material factors did not also play a role, as clearly they did. Ideas constructed preferences that sometimes had their origins in material interests. In particular, the UK case and other anecdotal evidence support the idea that higher-income countries actively pursue tax treaties with lower-income countries because this improves the competitive position of their own multinationals. Yet, in the UK, two competing ideas about how treaties would achieve this shaped the country's negotiating priorities. In some instances, the UK turned down an agreement in the face of strong competitive pressure, because it undermined the broader project embodied by the OECD model. Furthermore, even if rational interests did explain the actions of capital exporters, we also need to explain the willingness of capital importers to negotiate. This brings us back to the ideational mechanisms discussed above.

Changes in ideas and negotiating capabilities offer one explanation for differences in negotiating outcomes over time; another is changing priorities. The taxsparing clauses that were popular in tax treaties from the 1970s to the 1990s provided benefits directly to companies rather than eliminating double taxation. There is some positive evidence to suggest that these clauses stimulate investment in lower-income countries, yet they are not part of the modern tax standards package, and tax specialists have an ambivalent relationship with them. The OECD suggested in 1998 that there was "an emerging consensus on the need for a reevaluation," claiming that "the basic assumption underlying tax sparing is invalid," an argument that is much stronger with the move by most OECD countries toward exempting the foreign profits of multinationals from further tax. Yet taxsparing clauses were an important part of the balance of costs and benefits by lower-income countries at the time many agreements still in force today were negotiated. Furthermore, while tax-sparing clauses clearly motivated some of the particular negotiations considered in the case studies, they by no means explain all. Indeed, UK negotiators regarded tax-sparing clauses as an adjunct to the main function of tax treaties and fought off pressure to sign with Brazil that was largely motivated by the desire for tax sparing. When Zambia negotiated with the UK, and Vietnam negotiated with the United States, both dropped their demands for tax sparing in order to secure an agreement.

This historical account tells us that the global power shift that is currently under way is not enough to change the North-South politics of global tax governance, at least not overnight. The sections that follow consider why this might be the case. The established powers have a strong first-mover advantage baked into multilateral institutions that, for the time being at least, show no sign of losing their dominant 
position. This advantage is both material, in the content of soft and hard law, and ideational, through the consensus that prevails in an international tax community dominated by practitioners from the Global North, as well as in the nonexpert discourse about tax treaties, which still centers on the tax treaties myth. Even if powerful non-OECD states were to destabilize these existing instruments and ideas, it is not clear that their long-term interests will align with those of lowincome countries.

\section{Overcoming the First-Mover Advantage}

As we saw in chapter 2, the story of lower-income countries' participation in the original League of Nations points to the need for some caution about the possibilities for change from the current openings. At the League, the first movers' agenda-setting power circumscribed subsequent discussions, limiting the options that lower-income countries could pursue. Had lower-income countries been in the room in 1925 rather than in 1928, the model tax treaties might have looked different. It is much harder to overturn an established consensus than to influence it in the first place. Similarly, had the United Nations rather than the OEEC/ OECD picked up the league's work after the Second World War, the more lowerincome-country-friendly settlement found in the Mexico Draft might have gained more currency. By the twenty-first century, the hegemonic position enjoyed by the OECD model, as a template both for bilateral treaties and for domestic laws, is difficult for all but the most self-confident emerging markets to challenge. As Eduardo Baistrocchi suggests, OECD tax standards benefit from network effects: any alternative would need to overcome their widespread use by other countries and hence by multinational companies, which creates a powerful incentive to conform. ${ }^{8}$ This analysis supports the historical institutionalist case that institutions created from decisions in the past condition the possibilities for action in the present.

Lower-income countries have tried to overcome the bias in the international tax regime at two levels: bilateral and multilateral. In the bilateral setting, a number have sought to renegotiate their tax treaties, strengthening their taxing rights and protecting them against tax avoidance. The results are mixed at best. Figure 8.1 gives the outcomes of 114 renegotiations by lower-income countries, comparing the overall source taxing rights permitted by the original treaty and the renegotiation. Distance above (below) the line shows how much the renegotiation improved (reduced) the balance of taxing rights from the perspective of the lower-income country. The outcomes vary significantly, and the original content of the treaty is a strong predictor of the renegotiated treaty that replaces it. 


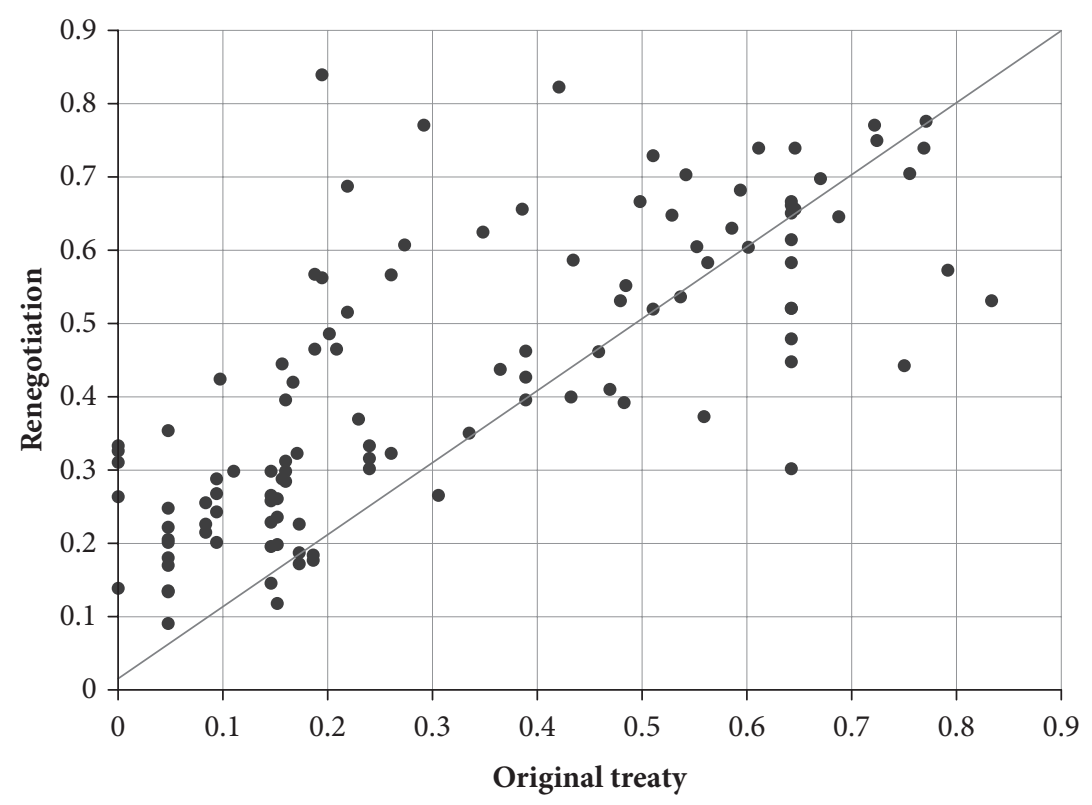

FIGURE 8.1. Tax treaty negotiations by lower-income countries measured using the overall index of source taxing rights

Source: Martin Hearson, “Tax Treaties Explorer," 2020, http://treaties.tax.

As chapter 6 illustrated, Zambia's renegotiations did generally strengthen its taxing rights, but the improvements to each treaty were relatively small, with give and take characterizing the renegotiation. In contrast, the most dramatic improvement by an African country, Rwanda's treaty with Mauritius, was obtained by first canceling, then renegotiating the treaty. This illustrates a point made throughout this book's empirical chapters that lower-income countries often underestimate their power, since their treaty partners may have a greater desire to obtain and maintain a treaty than they realize. This is certainly the case for Mauritius, whose position as an offshore financial center relies in large part on its network of tax treaties. The data set compares treaties against a fairly modest yardstick, and no lower-income country has succeeded in negotiating a tax treaty with a major capital-exporting state on any basis other than the OECD model or equivalent.

What about the multilateral track? Lower-income countries were only given a seat at the OECD table in 2016, but they have long been able to participate in the UN tax committee's deliberations. Beyond the modest improvements to the OECD model that the UN model has embodied since its publication in 1980, the committee has little else to show in terms of tangible tools to help lower-income countries counteract the bias in the international tax system. No doubt interventions such as 
negotiation manuals and capacity-building programs can help, but they also perpetuate the notion of good practice embodied in the OECD-UN complex. At the level of personnel, this should not be surprising, given the overlapping memberships between UN and OECD committees highlighted in chapter 4. At committee meetings, the social interactions between members from OECD countries are also quite visible, in comparison with less networked members from lower-income countries. At the time of writing, the UN committee's subgroup working on transfer pricing includes three former OECD secretariat staff who were responsible for its work on that topic, all of whom subsequently moved into the private sector.

There are signs, however, that lower-income countries are becoming more effective in their use of the opportunities provided by the UN. In 2017 the new committee elected an African cochair for the first time. According to participants in the discussions, this was because the committee's seven African members united around the same one member. ${ }^{9}$ Members from OECD countries, who have always caucused ahead of UN committee meetings, did the same, and the stalemate was resolved through the election of two joint chairs for the first time. Just before this, the committee agreed to include an article permitting withholding taxes on technical services - an issue that has animated bilateral negotiations as early as 1972—into the UN model, where it finally appeared in 2017.

As for the OECD's new Inclusive Framework, the initial signs suggest that changes in institutional form have given lower-income countries some formal scope to participate, but that the OECD's de facto control over discussions has not been relaxed. According to conversations with several representatives of lowerincome countries who have participated in the Inclusive Framework, as well as other participants and observers, lower-income countries' interventions are politely listened to but not taken on board if they differ from the existing consensus. "Everybody knows that developing countries can say their position, but proposals are put by the developed countries," according to one,${ }^{10}$ while another concurred that "we feel that everything is predetermined from the G20 and the OECD.... They say it is on an equal footing, but that is not true." 11 One former delegate from an OECD country suggests that this dynamic is less nationally derived and more because of "a group of friends meeting each other every couple of months." 12 Effective influence in the OECD committees, this person suggested, depended on going to the same restaurant and drinking wine in the same Parisian apartment as the most influential committee members.

There is some indication that this situation may be subject to change. Both the G20 emerging market countries and the ATAF-which had observer status on behalf of African countries-have claimed some success in shaping OECD standards during the BEPS project, although these changes are certainly only marginal and incremental. ${ }^{13}$ Discussions in the Inclusive Framework on the only major out- 
standing BEPS agenda item, the digital economy, have moved from implementation to standard setting. A policy paper drafted by India, Ghana, and Colombia on behalf of the Intergovernmental Group of 24 lower-income countries was noted by the head of the OECD secretariat to have played a role in shaping the agenda for discussions, which at the time of writing have yet to reach any outcome. ${ }^{14}$

These developments confirm that preexisting institutions created among a core of countries do lock peripheral states into participation in regimes that do not reflect their interests, and entrench interstate power dynamics. Lower-income countries may be able to overcome these lock-in effects, but opportunities for change are likely to be incremental. ${ }^{15}$ They also demonstrate that the level of influence lower-income countries can exert within those boundaries is not predetermined. One variable that seems to determine latitude for change is the capacity of lower-income countries' representatives to organize into caucuses and work together. Here the OECD representatives have clear advantages: the status quo is a long-standing consensus among them; they form a social group whose shared understanding of the normative and technical basis of cooperation is maintained through regular informal, as well as formal, interactions.

One side effect of the increased intensity of multilateral bargaining involving lower-income countries, however, is the beginning of a new counterhegemonic intersubjective understanding of the international tax regime that emphasizes its unfairness. Consider a PowerPoint slide from a Ghanaian negotiator-now the cochair of the UN Tax Committee: "International tax rules ... [are] not in [the] interest of developing countries." 16 This echoes a written statement from Chinese tax officials: "For a long time, in their competition with developing countries for more tax resources (tax base), higher-income countries have obtained most of the benefits generated by MNEs [multinational enterprises] by relying on their dominant position in formulating the rules and superiority in technology and intangible property, while developing countries have obtained a very small share of the profits." 17 This new discourse was also on display at a meeting of Frenchspeaking African tax officials attended by the author in 2018. According to one participant whose country had joined the OECD, "They arranged everything first and then invited us into the Inclusive Framework. But there are nonetheless some opportunities for African countries there."18

\section{Resisting the Logic of Appropriateness}

The development of this new discourse among technocrats matters because confrontation in the international tax regime takes place in the technical sphere. Indeed, the politicization of corporate tax policy is often framed by members of 
the tax community as a risk in itself: it signals policy instability and decisions that prioritize dogmatic principles over economic efficiency. This may in part explain OECD countries' preference for limiting discussion of international tax rules to its technocratic CFA and a UN committee of experts whose members participate only in a personal capacity. Just as the institutional setting of the OECD is higherincome countries' home turf, so for the time being is the "expert" sphere. Lowerincome countries need to build knowledge on their own terms, rather than simply assimilating knowledge originating in the North.

Of the cases described in this book, Cambodia illustrates most vividly how this might work. Over a decade, Cambodia's General Directorate of Taxes higherincome the institutional knowledge and capacity it needed to negotiate tax treaties, relying on expert advice but being ready to challenge it when necessary. The result: Cambodia's treaties are among the most expansive in the taxing rights that they retain-measured using the index of overall source taxing rights, Cambodia has the most sovereignty-preserving treaty network of any lower-income country. Crucially, its treaties include some provisions important to Cambodia that break the mold, in small but important ways.

Looking elsewhere, there is some small evidence of a shift in the center of gravity. The UN's inclusion of an article on technical service fees in its model convention, forty-five years after such articles began to become part of lowerincome countries' negotiation platforms, underscores this, as do the data showing an increased prevalence of this article in treaties signed by lower-income countries (figure 8.2). As we saw in chapter 1, tax treaties signed by lower-income countries are also including more generous PE clauses as time goes on, increasing the circumstances in which they are able to levy taxes on the profits made locally by foreign companies. There are some caveats to both of these changes, however. First, they are occurring predominantly within treaties signed between lower-income countries. Tax treaties signed between OECD members and lower-income countries are no more generous in their PE definition now than in the 1970s, on average. Many OECD members still resist articles concerning technical service fees. The UK is a notable example: in the course of researching this book I encountered one example of a country that capitulated to the UK on this issue, and three that had walked away from negotiations because of it. Even where OECD countries agree to include such an article, they naturally extract other concessions in return. The second caveat is that these changes are still taking place within the existing tax treaty paradigm. Overall, tax treaties signed by OECD countries are becoming more, not less, restrictive in the limitations they impose on the taxing rights of lower-income countries.

To look for examples of countries breaking more significantly with the established norms of the international tax regime, we must look beyond tax treaties. 


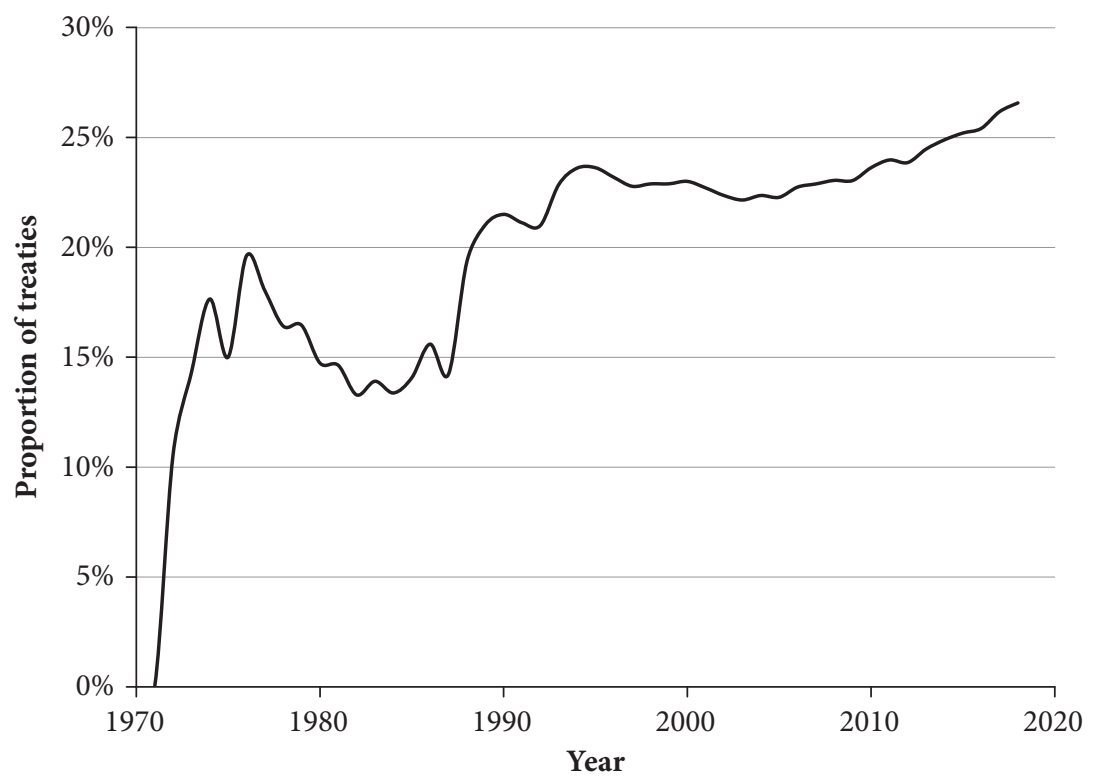

FIGURE 8.2. Cumulative proportion of lower-income countries' treaties including a technical service fee withholding tax clause

Source: Hearson, "Tax Treaties Explorer."

Rwanda, for example, when introducing a broadly OECD-compliant income tax code in 2018, included a provision permitting it to impose a tax surcharge on payments of royalties and technical service fees exceeding 2 percent of a firm's turnover, thus limiting its vulnerability to tax avoidance. ${ }^{19}$ The international tax consensus dictates that, so long as these payments can be justified, they should not be penalized in the tax system. India and China, meanwhile, have pushed ahead with interventions that chip away in other ways, laying claim to a much bigger share of the tax base than OECD norms permit. ${ }^{20}$ Lower-income countries are also beginning to innovate by introducing new taxes on the digital economy that break with consensus. $^{21}$

The OECD's work on the digital economy, while not driven primarily by lowerincome countries, has broken new ground, with an agreement to pursue solutions that "go beyond" the underlying norms and open up the distributional discussion that was previously off limits, with the intention of shifting the balance of taxing rights toward greater source taxation. ${ }^{22}$ This shift has been driven by political pressures across higher-income and lower-income countries, which are so great as to threaten the previously stable consensus. According to the US Treasury's deputy assistant secretary for international tax affairs, speaking in February 2019, "The 
world risks an accelerating trend towards unilateral actions that would jeopardize the coherence of the international tax system."23 If, indeed, we are observing the beginnings of a more organized lower-income country bloc that demands reform, experience in other areas of global economic governance, such as the failure of the Doha round at the WTO and the Copenhagen climate change summit, suggests that its initial impact will be a period of unilateralism and stalemate, rendering existing global institutions of cooperation ineffective.

\section{Confronting the Tax Treaties Myth}

What about the political accountability of negotiators? One lesson from this book is that for any new discourse about the international tax regime to gain traction, it needs to extend beyond the technocratic sphere to the political one. This can empower negotiators reticent to rock the boat, as well as insulate them from making decisions based on the prevailing social norms of the transnational tax community. In interviews, I noticed a new cohort of highly skilled, knowledgeable, and experienced tax negotiators from lower-income countries who vocally expressed critical opinions about the current state of the tax treaty regime.

There is some evidence that the international tax regime more generally has escalated as a political concern in lower-income countries. In 2015, a high-level panel chaired by former South African president Thabo Mbeki published its report on illicit financial flows (IFFs), which was endorsed by the African Union council. The report noted that "double taxation agreements can contain provisions that are harmful to domestic resource mobilization and can be used to facilitate illicit financial outflows. We recommend that African countries review their current and prospective double taxation conventions, particularly those in place with jurisdictions that are significant destinations of IFFs, to ensure that they do not provide opportunities for abuse." 24

Much more energy has been generated around the issue of tax treaty abuse than on the unfairness built into tax treaties by design. An exception is perhaps the debate over the status of the UN Tax Committee, discussed earlier in this chapter. Foreign ministries and finance ministries of lower-income countries, as well as their tax authorities, appear to be concerned that the existing committee's work to date had not displayed the ambition that they were increasingly seeking. This is why the G77 group of lower-income countries set out "the need to fully upgrade the [UN] Tax Committee into an intergovernmental body." 25

But lifting discussion about tax treaties from the technical to the political sphere brings with it the attendant risks of slipping further into a cycle of negotiations that are not grounded in a coherent analysis of costs and benefits. A clear message 
from this book is that a competent team of negotiators can only go so far if they are embedded within a government machine pervaded by the logic of tax competition. Indeed, two negotiators from African countries interviewed in 2018 gave examples of negotiations that had been undermined by senior government ministers who were keen to ink an agreement with the other country as quickly as possible and who acted over the heads of their negotiation teams. ${ }^{26}$ Catherine Ngina Mutava collected numerous further examples. ${ }^{27}$ Many lower-income countries continue to sign tax treaties because of a perception that they must keep up with their competitors and neighbors. Cambodia's eventual, admittedly reluctant; capitulation to the logic propounded within ASEAN is one example of this, following the example of Zambia's SADC-inspired treaties.

The political pressures do not all operate in one direction, however. As the Zambia case showed, the politicization of multinational companies' tax affairs, widespread over the past decade, can put a brake on negotiations. In Ghana, for example, opposition parties threatened to hold up the ratification of four treaties through the country's parliament in $2018 .^{28}$ Kenya's government failed to win the court case brought against its treaty with Mauritius, which was struck down on the grounds that the ratification had not followed proper procedure, despite the permanent secretary to the Treasury's defense of it in evidence. The finding was on a technicality, and the court upheld the broader constitutionality of the treaty's content and the process of ratification, concurring that as an "agreement" it was not subject to the same strictures as a treaty. ${ }^{29}$ The political impact of the court case, which for the first time brought tax treaties into the domain of public debate, cannot be underestimated.

Concerns in higher-income countries have also placed pressure on governments of higher-income countries to reconsider their negotiating approach. An unprecedented vote in the UK's parliament on its treaty with Lesotho in 2018 was the first time that a tax treaty has not been waved through by its lawmakers. Both Ireland and the Netherlands conducted reviews into the economic impact of their treaty networks on lower-income countries, after which they offered renegotiations to lower-income countries identified as adversely affected. ${ }^{30}$ The European Commission is among the organizations urging major capital-exporting nations to conduct such analyses and has produced a toolkit of suggestions for how they might do so. ${ }^{31}$

\section{New Allies and New Enemies}

While Cambodia, Zambia, and Vietnam will need to punch above their weight to shape the contours of the international tax regime, the same is not true for some 
emerging markets. China has already begun to shape the international tax regime, pushing the OECD toward adapting its transfer pricing rules to absorb some Chinese characteristics. ${ }^{32}$ The OECD has been replaced by a G20-OECD complex in which countries including Saudi Arabia, South Africa, and India now have seats at the top table. Yet, as the contours of the global economy shift, it is far from clear that countries such as these share the same interests as Cambodia, Vietnam, and Zambia. Indeed, it is possible that we will see the formation of a higherincome-country-emerging market bloc, making it harder, not easier, for lowerincome countries to shift the center of gravity of the tax treaty regime. These fears are grounded in both bilateral and multilateral developments.

At the bilateral level, many of the least generous tax treaties being signed by lower-income countries are with emerging markets that are becoming capital exporters. Among the countries that have signed the most treaties with lower-income countries this century, Turkey, Mauritius, and China appear to be the most aggressive negotiators, with the most residence-based treaties, followed by Middle Eastern states with sovereign wealth funds, Kuwait and the United Arab Emirates (table 8.1). Turkey's position in this table surprised its negotiators when I informed them at a European Commission workshop in 2018. China's bulldozing approach can be seen from Cambodia's tax treaties: while treaties with ASEAN members stand out for their uniform source-based nature, its agreement with China is anomalous, at the other end of the spectrum. Uganda, at least, has left its treaty with China unratified because of its one-sided terms. Lower-income countries cannot rely on large emerging markets that have more clout with international tax rulemaking to carve out changes to model treaties that will benefit them.

TABLE 8.1. The ten countries that have signed the most tax treaties with lower-income countries since 2000

\begin{tabular}{lcc}
\hline countRY & $\begin{array}{c}\text { INDEX OF OVERALL SOURCE } \\
\text { TAXING RIGHTS-AVERAGE }\end{array}$ & NUMBER OF TREATIES \\
\hline Turkey & 0.31 & 14 \\
Mauritius & 0.37 & 17 \\
China & 0.38 & 17 \\
Kuwait & 0.42 & 23 \\
United Arab Emirates & 0.42 & 31 \\
Portugal & 0.43 & 13 \\
South Africa & 0.46 & 14 \\
Iran & 0.49 & 14 \\
Qatar & 0.52 & 18 \\
Saudi Arabia & 0.53 & 14 \\
\hline
\end{tabular}

Source: Martin Hearson, “Tax Treaties Explorer," 2020, http://treaties.tax. 
In particular, China's advocacy in multilateral forums appears to be aimed not at generating general benefits for all lower-income countries but at carving out special benefits for China. Rhetorically, China has presented itself as a champion of lower-income-country concerns. A Chinese State Administration of Taxation web page approvingly quotes a Chinese academic observing that "the formulation of the global tax rules has long been dominated by developed countries, with appeals of developing countries not taken into full consideration." ${ }^{33}$ It goes on to document concerns common to a wide range of lower-income countries. Yet China's most significant break with OECD rules to date, which grabs a bigger share of the multinational tax base, is based on the "location specific advantages" that it argues make firms more profitable in China than elsewhere. This will benefit China at the expense of lower-income countries as well as OECD members, as demonstrated by the official view that China's market premium is "unique in the world and inimitable by other small and medium-sized developing countries."

\section{A Call for New Research}

This book points toward the need to question some of the priorities and assumptions that have characterized thinking about international tax up to now. It is not just policymakers who have been influenced by the seductive logic behind socalled Double Taxation Agreements and the other institutions of the international tax regime. Previous studies addressing this question have tended to assume that tax treaties are primarily the product of capital-importing states' desire to stimulate investment, principally by eliminating double taxation. Convergence on the Western-dominated institutions of international tax cooperation is still often characterized as based on rational calculation that the costs in terms of investment from not conforming exceed those in terms of tax revenue from participation. Critical accounts in the legal literature frequently disagree, arguing that lowerincome countries would do better to keep at a distance from the OECD and its model tax treaty, but they are at a loss to explain why they have not done so. Lowerincome countries are losing out because they arrived late on the scene, but it is as much ideas as institutions that are path dependent. Rational calculation alone often cannot explain why actors in lower-income countries have come to the conclusion that it is a good idea to sign tax treaties as they have done, and analysis focused on interest groups fails to account for divisions within particular types of actors, including inside government. This book's detailed empirical research shows that the way the problem and the solution are constructed differs depending on an actor's technical expertise. 
A first direction for future scholarship is therefore toward an understanding of the causal role played by ideas about corporate taxation. Too often, international tax cooperation has been a technocratic area of policy, with decisions made far from the more boisterous world of tax-and-spend politics. Yet it is in this more political domain that it belongs, and many lower-income countries have found that a failure to combine the technical capacity of negotiators with political buy-in to the negotiation strategy has led to poor, incoherent decision making that comes back to haunt them. We could say the same about the decisions made by higherincome countries that led to their post-financial-crisis travails: the current wave of politicization of corporate taxation - and in some countries, of tax treaties themselves - is really a backlash against decades of decisions made by technocrats and politicians that hollowed out the tax base, obscured from the full view of stakeholders. ${ }^{35}$ In lower-income countries, which rely heavily on taxation from multinational companies, these decisions, which have bound subsequent governments into tax treaties, tax incentives, stability agreements with mining companies, and so on, do not only undermine the state's ability to provide the public services expected by its citizens. They also compromise tax morale, and with it the nascent fiscal contract between citizens and the state.

A second direction for future research is toward a more grounded theorizing of the relationship between the Global North and the Global South in international tax cooperation. Literature on tax cooperation in international relations and international political economy has been almost entirely focused on tax avoidance, tax evasion, and tax havens, all areas where economic actors gain from the limits of international tax cooperation. ${ }^{36}$ The conclusion of this book, similar to that reached by Tsilly Dagan, is that more cooperation is not necessarily a good thing: if international tax rules worked perfectly, the outcome for lower-income countries would still be unsatisfactory, because the rules are biased by design. ${ }^{37}$

Consider the notion of tax competition, which is at the heart of how we theorize the motivations for cooperation. Economics and international political economy have long focused on the "race to the bottom," thought to result from competition between states for inward investment. The role of competition between capitalexporting states, which seek to increase opportunities for their outward investors, was rarely considered. Yet the truth is not too far from the allegations of the Russian and Polish delegates to the United Nations in the early 1950s (chapter 2): cooperation to relieve double taxation creates a favorable tax environment that promotes the expansion of multinationals from major capital-exporting states. As the headquarters of multinational companies have become more mobile, pitting those states against each other to attract multinationals' headquarters, competition for outward investment has intensified, and international organizations have raised concerns about the spillover effects on lower-income countries. ${ }^{38}$ Tax trea- 
ties are just one example of an increasingly complex story of tax competition among capital exporters, which may now be the most significant obstacle to more effective tax cooperation. ${ }^{39}$ To understand what these countries want when they negotiate a tax treaty, we need a more sophisticated model of their preferences that takes into account the use of international tax rules to provide financial advantages to mobile capital, rather than simply to maximize revenue. The focus in academic and policy discourse on competition among capital importers merely contributes to the tax treaties myth.

Even if we were to accept a significant role for inward investment-promoting tax competition, and for the double taxation problem itself, it does not necessarily follow that the consensus across the OECD-derived model tax treaties, which systematically shift the burden of double tax relief onto lower-income countries, is the inevitable solution. Again, some tax officials, on gaining sufficient understanding of tax treaties to realize this, question the standard treaty articles. But there has not been a concerted push to challenge the hegemonic status of the de facto settlement between higher-income and lower-income countries that is embodied by the OECD model. Here we need to better understand the strategic dilemmas and collective action problems faced by lower-income countries themselves. Why have they failed to maximize the gains possible from existing multilateral institutions, and within the parameters set by the model treaties for bilateral negotiations? Is it meaningful to think about a monolithic bloc of "lowerincome countries" given that powerful emerging markets are among the toughest negotiators with lower-income countries and pursue their own agendas in multilateral forums? The approach here, a "thick description" that captures how these issues are understood by negotiators and policymakers, has demonstrated that academics' assumptions about the answers to these questions do not always hold.

This book was written at a time when international tax, and increasingly tax treaties themselves, has become uniquely politicized, creating more interest from actors in lower-income countries in questioning the rules of the tax cooperation game. The timing is not entirely coincidental, and some of the analysis herein has contributed to public debates about the choices made by higher-income and lower-income countries over their tax treaties. Yet historical perspectives on the origins of lower-income countries' tax treaty networks are sorely lacking. During fieldwork in Uganda, civil servants were surprised that I knew much more about their country's past negotiations with the UK than they did. After I presented chapter 5 of this book to a group of African revenue officials, a revenue authority commissioner approached me to say how surprised he was to learn of higherincome countries' own motivations for concluding tax treaties with lowerincome countries. 
This lack of historical perspective needs to be addressed for a number of reasons. First, many lower-income countries, including Zambia and Vietnam, signed treaties with their biggest sources of investment soon after independence or opening up. The result is that the taxation of much of their foreign investment is governed by agreements on terms reached by negotiators who may have had much less knowledge and experience than their current successors, reaching tradeoffs that were specific to the economic and political climate of the day. Second, a negotiated tax treaty is sticky: the consequences for a country's reputation of terminating a treaty may be more significant than not negotiating it in the first place, as a Zambian negotiator lamented..$^{40}$ Lower-income countries are subject to "policy drift," whereby domestic and international politics make it tough to alter their historically negotiated treaties, even as the economic context changes around them, potentially making the treaties costly in ways that could not have been anticipated. ${ }^{41}$ Third, negotiating positions are determined by precedent, with subsequent negotiations starting from the terms that a country has offered in the past.

Consider the 1973 UK-Kenya tax treaty, with which this book began. It was a Kenyan priority, as in many of the case studies in this book, to secure a tax-sparing clause so that British firms could benefit fully from Kenyan tax incentives. Such a clause is no longer necessary, as the UK has ceased taxing most of the foreignsource profits of British multinationals. The tough negotiation over the taxation of service fees occurred before the internet age had revolutionized the tax planning possible using such payments. On this basis, it might be a sensible strategy for Kenya to go back to the drawing board on this treaty, as it had originally done in the 1970s. The treaties it tore up then were biased against it because they had been imposed under colonial rule. Its treaties today are also biased, but this is a consequence of a hegemony of ideas, not colonization. This hegemony operates differently at the expert and nonexpert levels, but the effect is the same: an imbalanced tax treaty system that serves the interests of OECD member states and multinational firms, to the detriment of development. 